\title{
The Middle Caddoan Period in East Texas: A Summary of the Findings of the East Texas Caddoan Research Group
}

Tom Middlebrook

Heritage Research Center, Stephen F. Austin State University

Timothy K. Perttula

Heritage Research Center, Stephen F. Austin State University

Follow this and additional works at: https://scholarworks.sfasu.edu/ita

Part of the American Material Culture Commons, Archaeological Anthropology Commons, Environmental Studies Commons, Other American Studies Commons, Other Arts and Humanities Commons, Other History of Art, Architecture, and Archaeology Commons, and the United States History Commons

Tell us how this article helped you.

This Article is brought to you for free and open access by the Center for Regional Heritage Research at SFA ScholarWorks. It has been accepted for inclusion in Index of Texas Archaeology: Open Access Gray Literature from the Lone Star State by an authorized editor of SFA ScholarWorks. For more information, please contact cdsscholarworks@sfasu.edu. 


\section{The Middle Caddoan Period in East Texas: A Summary of the Findings of the East Texas Caddoan Research Group}

\section{Creative Commons License}

\section{(c) (1) \&}

This work is licensed under a Creative Commons Attribution-NonCommercial 4.0 International License 


\title{
The Middle Caddoan Period in East Texas: A Summary of the Findings of the East Texas Caddoan Research Group
}

\author{
Tom Middlebrook and Timothy K. Perttula
}

\section{Introduction}

The second meeting of the East Texas Caddoan Research Group (ETCRG) met in San Antonio on October 27, 1996, to consider the archaeology of the Middle Caddoan period in East Texas. The meeting was arranged as a three hour symposium held in conjunction with the annual meeting of the Texas Archeological Society.

The meeting's format involved the informal presentation by several ETCRG members of major research findings along thematic lines for each of several river basins in the region. The presenters distributed handouts to participants and mixed their comments with slides, photographs, and the hands-on examination of a few selected artifacts. The presentations and discussions were tape-recorded, and transcribed and edited proceedings of the meeting are to be published in a future volume of the Journal of Northeast Texas Archaeology. Brief periods of discussion did occur between the presenters, and the audience participated as well, during the three hour meeting; however, the general consensus of the group was that more time was needed and there was much left to be discussed. This paper attempts to summarize the information presented during the ETCRG meeting, and may (we think) represent a good starting place for continued dialog on the archeology of the Middle Caddoan period, as well as further dialog on the organization and arrangement of future ETCRG meetings.

Eight handouts were available to the research group. Four were river basin archaeological summaries prepared by Maynard Cliff (the lower Sulphur River basin), Bo Nelson and Mike Turner (Cypress Creek Drainage basin), Tim Perttula and Brett Cruse (the upper and middle Sabine River basin), and Tom Middlebrook (Attoyac and Angelina River basins). Two handouts not associated with presentations were also prepared for the ETCRG members, namely archaeological summaries of the Middle Caddoan period by Tim Perttula for the middle Red River basin and the upper Sulphur River basin. Jim Corbin provided extensive information on the Middle Caddoan Washington Square Mound site (4INA49) in Nacogdoches County, while Bob Turner discussed archaeological materials found in three Middle Caddoan period cemeteries in Camp and Upshur counties.

\section{Definitions}

The term "Middle Caddoan" refers to a temporal period from A.D. 1200-1400 as set out by Story (1990). Relating specific archaeological components to this period is not easy in many cases. Sequences of artifacts and their associations have not been established convincingly in most portions of East Texas, and absolute chronometric studies of Caddoan sites in East Texas have been striking in their paueity, with the notable exception of the George C. Davis site in Cherokee County. Nevertheless, sufficient archaeological data from this time period are available throughout East Texas to warrant examining the Middle Caddoan period as an archaeologically (if not culturally) meaningful unit.

Although the Middle Caddoan period is explicitly a time construct for the purposes of the ETCRG symposium study, at least two other archaeological and cultural implications and nuances may have relevance for discussions relating to this taxonomic term. First, the Middle Caddoan period can have a developmental or processual meaning if one refers to it as representing a stage or distinct period of change from earlier to later broad patterns of cultural practices. Such a definition is appealing when focusing on the apparent differences in settlement patterns, subsistence practices, mortuary behavior, and socio-political hierarchy between Early Caddoan (ca. A.D. 900-1200) and Late Caddoan (ca. A.D. 14001680) groups in East Texas. But this sort of meaning places far too much importance on 
the two ends of the sequence and does not allow for the adequate emphasis on more finegrained analyses of cultural developments throughout the Caddoan occupation of the region. While diversity is the hallmark of the Middle Caddoan period archaeological record, this is probably more of a reflection on the dynamics of societal changes within and between Caddoan groups that reaches a culmination during that time, than it is a mark of a simple developmental transition.

Second, the Middle Caddoan period can subtly become a short-hand notation for a set of spatio-temporal archaeological units, such as phases. Indeed, several presenters made reference to the affiliation of Middle Caddoan period components with particular defined phases. For example, Maynard Cliff mentioned the relationship of Middle Caddoan sites in the lower Sulphur River area to the Haley phase defined in the Great Bend area of the Red River. He noted the appearance of a distinctive Middle Caddoan period ceramic tradition around A.D. 1300 in this part of the basin. Perttula remarked on the apparent affiliation of sites along the middle Red River and upper Sulphur River basins to the Sanders phase (however poorly defined), suggesting that these components of the Middle Caddoan period date from about A.D. 1100-1350. According to Nelson and Turner, and Bob Tumer, some probable Middle Caddoan sites in the Cypress Creek drainage have been previously assigned to the Whelan phase (e.g., Thurmond 1990). Robust taxonomic units for the Middle Caddoan period sequence south of the Sabine River do not exist, however. Middlebrook did present a tentative temporal division of previously defined "Angelina Focus" sites from the Attoyac and Angelina river drainages. To the ETCRG participants, these references to taxonomic units of one sort or another may prove useful, provided that the distinction between time units and phases is consistently made, and that convenient blocks of time do simply not become reified as cultural entities with assumed prehistoric Caddoan socio-cultural meaning.

\section{Settlements}

Caddoan settlement patterns during the Middle Caddoan period appear to vary somewhat from one stream drainage to another. The meaning of this variability in Caddoan settlement has not been explained, and future ETCRG meetings should take up the issue, perhaps in discussions of prehistoric Caddoan demographics in East Texas (Figure 1). 


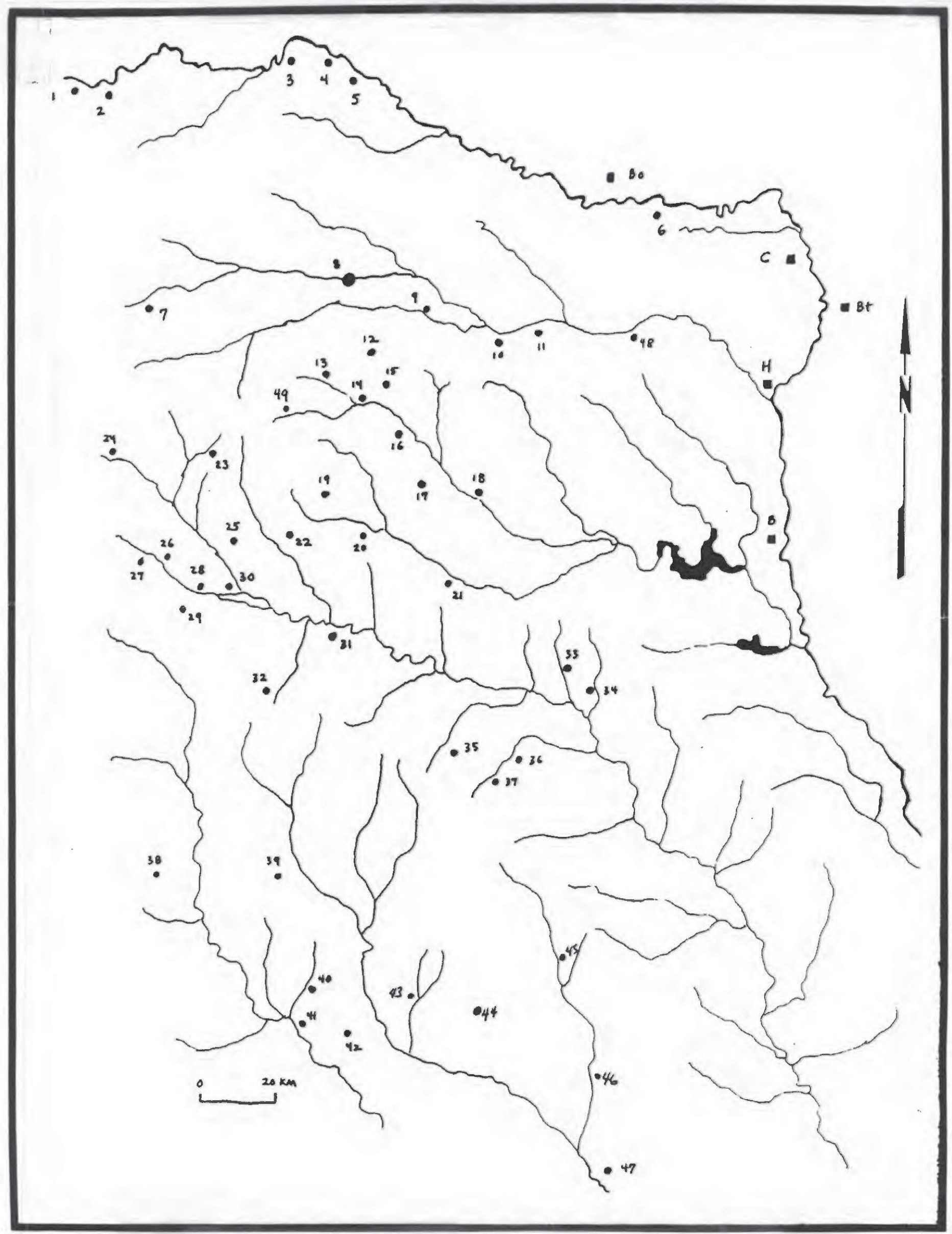

Figure 1. Known Middle Caddoan Period Archeological Sites in East Texas and Major Red River Caddoan Centers Occupied during the Middle Caddoan Period. 
Key to Figure 1

\author{
$\mathrm{Bo}=$ Bowman \\ $\mathrm{C}=$ Crenshaw \\ $\mathrm{Bt}=$ Battle \\ $\mathrm{H}=$ Haley \\ $\mathrm{B}=$ Belcher \\ 1. Harling \\ 2. Sanders \\ 3. Fasken \\ 4. Roitsch \\ 5. Holdeman \\ 6. Hatchel \\ 7. Hurricane Hill \\ 8. Little Mustang Creek sites \\ 9. 41TT670 \\ 10. $41 \mathrm{CS} 150$ \\ 11. Coker (41CS I) \\ 12. 41TT372 \\ 13. 41 FK 70 \\ 14. Benson's Crossing \\ 15. Crabb (41TT650) \\ 16. Harold Williams \\ 17. 41UR21 \\ 18. Big Oaks \\ 19. Griffin Mound \\ 20. 41 UR133 \\ 21. 41UR8 \\ 22. McKenzie \\ 23. Spoonbill \\ 24. 41RA65
}

\author{
25. T. M. Moody \\ 26. $41 \mathrm{WD} 518$ \\ 27. Yarbrough \\ 28. Crews \\ 29. Jamestown \\ 30. Carlisle \\ 31. Langford \\ 32. Bryan Hardy \\ 33. 41 HS74 \\ 34. Old Brown Place \\ 35. Oak Hill Village \\ 36. $41 \mathrm{PN} 14$ \\ 37. Musgano \\ 38. Pace McDonald \\ 39. 41CE42 \\ 40. 41CE289 \\ 41. George C. Davis \\ 42. 41CE290 \\ 43. 41NA20 \\ 44. Washington Square \\ 45. Tyson \\ 46. 41SA 123 \\ 47. 41SA89 \\ 48. Knight's Bluff \\ 49. 41FK7
}

Most of the large mound sites are restricted to the largest river basins. In the Red River basin, for instance, there are several mound complexes, frequently along the Red River itself; some occur with associated large communities and non-mound cemeteries. There are also dispersed sites in the floodplain of major streams and along the margins of nearby upland landforms. These sites contain house structures, middens, and cemeteries.

Middle Caddoan period settlement of the lower Sulphur River basin seems to have consisted primarily of scattered hamlets along upland margins, and on old levees in major and minor drainages; very few large villages or mound sites have been identified. Again, these residential sites contain house structures (sometimes overlapping), ramadas/arbors, middens, and cemeteries.

Both small and large settlements are seen in the Cypress drainage along major and minor tributaries. Three Middle Caddoan period mound sites are noted in the western part of the basin. There are a number of cemeteries in the Cypress Creek basin that apparently are not located immediately adjacent to a village or farmstead site, and thus they may represent burial areas for extended communities (perhaps presaging the more widespread development of community cemeteries after about A.D. 1500 in the Titus phase).

In the upper and middle Sabine River basin, there are apparently a number of large communities (covering from 2-3 hectares) as well as mound centers that are located along primary tributaries, and sometimes near their headwaters, but not along the Sabine River itself. The recently excavated Oak Hill village (4IRK214) in the middle Sabine River basin 
contained 42 overlapping circular and rectangular structures around a central plaza, as well as a single mound. Despite the size of the settlement at the Oak Hill Village site, there was no associated cemetery.

Very few Middle Caddoan period sites are known from the Angelina River basin. What is known suggests that settlement included an important multiple mound center (Washington Square), as well as villages along levees and high terrace margins with intense middens, house structures, and dispersed graves. The George C. Davis mound center to the west in the Neches River drainage continued to be occupied during the first half of the Middle Caddoan period.

\section{Subsistence Practices}

The practice of agriculture was used to some extent in the Middle Caddoan period in East Texas, and may have focused on the cultivation of maize and squash. However, the total amount of maize recovered in archaeological excavations from features and middens has been very small except for the findings at Oak Hill village. Also, very few stable carbon isotope studies of bioarchaeological remains have been performed and the results suggest a varying reliance on cultivated plants at this time.

Maize may have been a greater component of the diet of Caddoan people on the middle Red River, and $\mathrm{C} 12 / \mathrm{Cl} 3$ stable isotope values of -10.0 to -12.9 o/oo from the Sanders site (Wilson and Cargill 1993) support this notion. There is a suggestion from the paleobotanical findings in the upper and middle Sabine River basin that maize may have been more commonly grown and used there after A.D. 1300. Many Middle Caddoan period sites bear evidence of the frequent procurement and usage of hardwood nuts. Maygrass, tubers, and other wild plants were likely gathered. Deer were a major terrestrial resource, and there is only very limited evidence of bison hunting. Many small mammals-such as rabbit, opossum, and raccoon--have also been recovered from Middle Caddoan middens. Fish, reptiles, and birds are represented in Caddoan faunal assemblages, and they may have represented important resources for subsistence during portions of the year.

\section{Dating}

While thermoluminescence dates on ceramic sherds have been obtained from possible Middle Caddoan period sites in the upper Sabine and Sulphur River basins, and the archaeomagnetic dating of one feature at Hurricane Hill has also been performed, the great majority of absolute dates for the Middle Caddoan period have been derived from calibrated radiocarbon dates on charcoal and charred nutshells. Several sites in the Red River basin have also yielded radiocarbon dates that fall in the A.D. 1200-1400 period, though this was not discussed in the ETCRG meeting. Specific sites with calibrated dates presented to the conference included:

Basin

Lower Sulphur

Upper Sulphur

Cypress
Sites (number of dates)

Knight's Bluff (2)

$41 \mathrm{CS} 150(1)$

$41 \mathrm{CS} 155 / 156(1)$

Coker (1)

Hurricane Hill (6)

41TT11 (2)

$41 \mathrm{TT} 372$ (3)

4IUR133 (1) 


\author{
4IURI42 (1)
}

Sabine

$41 \mathrm{HS} 74$ (1)

Oak Hill Village (8)

Redwine (1)

Carlisle (1)

Spoonbill (3)

McKenzie Mound (8)

Hudnall-Pirtle (2)

Angelina

Washington Square (12)

Tyson (4)

Sawmill (1)

Blount (1)

Neches

George C. Davis (20+)

\title{
Mounds
}

Ceremonial mound centers built and used during the Middle Caddoan period are present in most of the major river basins in East Texas. Unfortunately, detailed information concerning mound-building activity during this time period is limited because: (a) some sites have never been systematically investigated, (b) some sites were tested or excavated more than 50 years ago without the benefit of modern techniques of study, or (c) the results of investigated sites have not been published. Mounds have been found either in single or multiple mound settings and have included examples of sub-structural, platform, and mortuary types.

The Fasken, Roitsch, and Sanders sites are important middle Red River civicceremonial centers that had mounds that were apparently built and used during the Middle Caddoan period. While Maynard Cliff mentioned that no unequivocal Middle Caddoan mound center is known in the lower Sulphur River basin of Texas, he discussed three mound sites in the Great Bend area of the Red River with possible Middle Caddoan period components (Haley, Hatchel, and Cabe), and noted seven single lower basin mounds (41BW53, 41BW76, Coker [41CS1], T. S. Montgomery, 41RR3, 41RR190, and 41 RR200) that may have Middle Caddoan components. Three mound centers are located in the Cypress Creek basin (Hale, Keith, Davis-McPeak [41UR4/99]), and a number of substructural mounds are seen along north and south-flowing tributaries of the Sabine River (McKenzie, Bryan Hardy, Oak Hill Village, Jamestown, 41WD7, and Colony Church) in the upper and middle parts of the basin. Apart from a couple of candidates in the Neches River drainage not considered during this symposium because they are poorly known, Washington Square represents the only identified Middle Caddoan mound center south of the Sabine River basin other than the venerable George C. Davis site (Story 1997).

\section{Mortuary Practices}

Small cemeteries are known from a number of Middle Caddoan sites in the northern portions of East Texas, that is, the area from the Red River to the Sabine River basin. No organized cemetery or cluster of graves has been identified from this period south of the Sabine River drainage, however. Less commonly known are large cemeteries (e.g., Turbeville site [41WD20] and 41HS144), those with 20 or more individuals, or mortuary mounds (e.g., Haley and Washington Square). While a few double interments and at least one multiple internment in a shallow shaft grave at the Crews site (41WD371) have been 
noted during the Middle Caddoan period, most burials are single interments. Individuals were typically placed in extended supine position with the heads often oriented east, southeast, or south. At the Sawmill site in the Angelina River drainage, two individuals were placed in a semi-flexed position and one was in an extended prone position. Three infants were buried in an apparent house floor at the Tyson site (41SY92).

Cremations have not been described from Middle Caddoan period sites. Ceramic vessels were placed with most interred individuals, although the extended burials at the Hurricane Hill site in the upper Sulphur River basin lacked grave goods. Other kinds of grave goods placed with the Caddoan individuals included ear spools or similar objects (of stone or bone), columnella and olivella beads, carved shell inlays, mussel shells, bird bone flageolets, deer ulna awls, deer antler, pipes, and arrow points. The ETCRG should consider undertaking a careful study of Middle Caddoan mortuary practices, focusing on possible social, gender, or age differences in burial treatment or in the kinds of associated grave goods.

\section{Ceramic Traits}

Ceramic assemblages from Middle Caddoan period sites are noteworthy for their apparent stylistic diversity. A few temporal and geographic generalizations, however, can be made. Overall, assemblages from earlier Middle Caddoan sites in the area from the upper Sabine River basin northward to the middle part of the Red River are more likely to display plain red slipped vessels (usually bowls and carinated bowls), which to some (but see Schambach 1997) suggest their broad affiliation with the Sanders phase. Other sorts of ceramics that seem to characterize the Middle Caddoan period in these areas include the defined types Sanders Plain, Sanders Engraved, Canton Incised, and Maxey Noded Redware, and some Crockett Curvilinear Incised and Hickory Engraved (probably during the first half of the period). Brushing is very uncommon in sites occupied before about A.D. 1200 , but its frequency steadily increases throughout the period over all of East Texas except for the Middle Red River and upper Sulphur River basins. Ceramic types often associated with the Haley and Bossier phases (Haley Complicated Incised, Haley Engraved, Red River pipes of the Haley variety, Pease Brushed-Incised, Maddox Engraved, and Sinner Linear Punctated) are especially common later in the Middle Caddoan period. This diversity in ceranic assemblages (with interesting decorative variations on a theme and amalgamations of diverse styles/decorative elements) appears to broaden over time, especially in the Sabine and Angelina River basins, and warrants further research consideration by the ETCRG.

Certain engraved motifs seem to be characteristic of Middle Caddoan period ceramic assemblages throughout most of East Texas. A listing of these includes: pendant triangles (small ones often excised, and larger ones frequently cross-hatched), pendant spirals, ladders, branches, ribbons with closely spaced parallel lines or cross-hatching, zones of diagonal lines or large cross-hatching, negative S-shaped scrolls, vertical scrolls, circles, concentric circles, semi-circles (occasionally off set across parallel lines), small circles with radiant lines ("sunbursts"), circles and crosses, and engraved rattlesnakes/serpents.

Vessel forms include simple bowls, carinated bowl, neckless bottles, ollas, globular and elongated (some shouldered or four cornered) bottles with medium to long necks, beaker-shaped jars, and globular jars with everted rims. Neck-banded rims are occasionally seen on jars in Middle Caddoan sites in the Sabine and Neches river basins. Scalloped rims, rim tabs, lugs, and strap handles are present in many Middle Caddoan period ceramic assemblages, and lip notching is a notable lip treatment in the upper Sabine River basin. Interior thickening is seen on some bowl and carinated bowl rims. 


\section{Concluding Remarks}

In our opinion, the second ETCRG meeting was very successful, and it promises to be only the first in a long list of successful cooperative ventures of the group. Through a concentrated focus on a particular topic or theme--in this case the archaeology of the Middle Caddoan period--and the active participation, hard work, and dedication of many ETCRG members, much new information (and some new thinking) about the Caddoan archaeology of East Texas has been gained and shared. We look forward to hosting and arranging equally productive ETCRG meetings on other topics and themes in the future.

\section{References}

Schambach, F. F.

1997 Continuing the Discussion of the Spiroans and their Entrepots: A Reply to Brook's Critique of my New Paradigm for the Archeology of the Arkansas Valley. Caddoan Archeology 7 (No. 4):17-46.

Story, D. A.

1990 Culture History of the Native Americans. In The Archeology and Bioarcheology of the Gulf Coastal Plain, by D. A. Story, J. A. Guy, B. A. Burnett, J. C. Rose, M. D. Freeman, D. G. Steele, B. W. Olive, and K. L. Reinhard, pp. 163-366. Research Series No. 38. 2 Vols. Arkansas Archeological Survey, Fayetteville.

1997 1968-1970 Archeological Investigations at the George C. Davis Site, Cherokee County, Texas. Bulletin of the Texas Archeological Society 68, in press.

Thurmond, J. P.

1990 Archeology of the Cypress Creek Drainage Basin, Northeastern Texas and Northwestern Louisiana. Studies in Archeology No. 5. Texas Archeological Research Laboratory, The University of Texas at Austin.

Wilson, D. and D. Cargill

1993 Stable Isotope Analysis from the Sanders Site (41LR2). Caddoan Archeology Newsletter IV (No. 3):3. 